\title{
Psychosocial Nursing Care With Anxiety Problems in Hypertensive Patients: A Case Study
}

\section{Verdalius Amazihono}

\author{
verdaliusamz@gmail.com
}

\section{BAB 1 \\ PENDAHULUAN}

\section{Latar Belakang}

Hipertensi merupakan salah satu masalah kesehatan yang cukup berbahaya di dunia, karena hipertensi merupakan faktor risiko utama yang mengarah kepada penyakit kardiovaskuler seperti serangan jantung, gagal jantung, stroke dan penyakit ginjal yang mana pada tahun 2016 penyakit jantung iskemik dan stroke menjadi dua penyebab kematian utama di dunia (WHO, 2018). Hipertensi merupakan tekanan darah tinggi dimana tekanan sistolik $\geq 140 \mathrm{mmHg}$ dan diastolic $\geq 90 \mathrm{mmHg}$. Salah satu penyakit tidak menular dan merupakan faktor risiko utama dari stroke, infark miokard dan penyakit ginjal kronik adalah hipertensi, dimana tekanan darah sistolik $\geq 140 \mathrm{mmHg}$ dan diastolik $\geq 90 \mathrm{mmHg}$. Hal tersebut diakibatkan karena adanya perubahan gaya hidup dan rendahnya tingkat pengetahuan seseorang tentang kesehatan (Arifin, 2016).

Berdasarkan data menurut WHO (World Health Organization) tahun 2015 menunjukkan sekitar 1,13 miliar orang di dunia menderita hipertensi, yang berarti setiap 1 dari 3 orang di dunia terdiagnosis menderita hipertensi. Jumlah penderita hipertensi di dunia terus meningkat setiap tahunnya. Diperkirakan pada 2025 akan ada 1,5 miliar orang yang terkena hipertensi serta setiap tahun ada 9,4 juta orang meninggal akibat hipertensi dan komplikasi. Kejadian hipertensi lebih banyak diderita pada pralansia dan lansia dibandingkan dengan kelompok umur yang lebih muda.

Prevalensi penderita Hipertensi di Indonesia menurut Badan Penelitian dan Pengembangan Kesehatan (BalitBanKes) melalui data hasil Riset Kesehatan Dasar (Riskesdas) 2018 saat ini sebanyak 34,1\% dimana mengalami kenaikan dari angka 
sebelumnya di tahun 2013 yaitu sebanyak 25,8\%. Hipertensi adalah tekanan darah persisten dimana tekanan sistoliknya di atas $140 \mathrm{mmHg}$ dan tekanan diastoliknya $>90$ $\mathrm{mmHg}$. Pasien ansietas akan mengalami peningkatan tekanan darah, akibat dari adanya peningkatan adrenalin, kondisi ini dapat membahayakan bagi pasien hipertensi. Oleh karena itu, pasien hipertensi yang mengalami ansietas memerlukan penanganan yang baik dalam menurunkan ansietasnya.

Ansietas adalah keadaan emosi dan pengalaman subyektif individu, tanpa objek yang spesifik karena ketidaktahuan dan mendahului semua pengalaman yang baru seperti masuk sekolah, pekerjaan baru, atau melahirkan anak (Stuart, 2009). Kecemasan merupakan suatu keadaan perasaan gelisah, ketidaktentuan, ada rasa takut dari kenyataan atau persepsi ancaman sumber aktual yang tidak diketahui masalahnya (Pardede \& Simangunsong, 2020). Kecemasan merupakan suatu respon psikologis maupun fisiologis individu terhadap suatu keadaan yang tidak menyenangkan, atau reaksi atas situasi yang dianggap mengancam (Hulu \& Pardede, 2016)

Penatalaksanaan hipertensi terdiri dari terapi farmakologi dan non farmakologi. Salah satu manajemen non farmakologis bagi pasien hipertensi dengan kecemasan adalah relaksasi progresif. Tujuan dari teknik relaksasi adalah mencapai keadaan relaks menyeluruh, mencakup keadaan relaks secara fisiologis, secara kognitif dan secara behavioral, secara fisiologis, keadaan relaks ditandai dengan penurunan kadar epinefrin dan non-epinefrin dalam darah, penurunan frekuensi denyut jantung (sampai mencapai 24 kali per menit), penurunan frekuensi napas (sampai 4-6 kali per menit), penurunan ketegangan otot, metabolisme menurun, vasodilatasi dan peningkatan temperatur pada ekstremitas. Relaksasi progresif sampai saat ini menjadi metode relaksasi termurah, tidak memerlukan imajinasi, tidak ada efek samping, mudah untuk dilakukan, serta dapat membuat tubuh dan fikiran terasa tenang, rileks, melawan ketegangan dan kecemasan serta lebih mudah untuk tidur (Davis dalam Ari, 2010) Beberapa penelitian sebelumnya tentang relaksasi progresif, telah menunjukkan manfaat dalam mengatasi berbagai masalah kesehatan terutama mengurangi ansietas atau kecemasan, dan berkurangnya kecemasan ini mempengaruhi berbagai gejala psikologis dan kondisi medis

Berdasrkan hasil survey pada pasien di jalan bakti luhur gang rahayu no. 74 , didapatkan bahwa pasien saat diajak komunikasi telihat gelisah, bicara cepat dan dan kontak mata 
tidak fokus, saat dilakukan pemeriksaan TTV didapatkan tekanan darah pasien tinggi denyut dan denyut nadi cepat. Saat ditanya mengapa terlihat gelisah, pasien menjawab khawatir akan penyakit Hipertensi nya karna sudah tidak pernah kontrol lagi dan umur yang kini sudah menua sehingga tidak bisa melakukan banyak aktivitas terutama kegiatan.

\section{Tujuan}

\section{Tujuan Umum}

Untuk memberikan asuhan keperawatan pada Tn. A dengan masalah kecemasan.

\section{Tujuan Khusus}

1. Mahasiswa mampu melakukan pengkajian pada Tn. A dengan masalah kecemasan.

2. Mahasiswa mampu menegakkan diagnosa pada Tn. A dengan masalah kecemasan.

3. Mahasiswa mampu membuat intervensi pada Tn. A dengan masalah kecemasan.

4. Mahasiswa mampu melakukan implementasi pada Tn. A dengan masalah kecemasan.

5. Mahasiswa mampu membuat evaluasi pada Tn. A dengan masalah kecemasan. 


\section{BAB 2}

\section{TINJUAN TEORITIS}

\subsection{Konsep Hipertensi}

\subsubsection{Defenisi}

Hipertensi adalah tekanan darah persisten dimana tekanan sistoliknya di atas 140 $\mathrm{mmHg}$ dan tekanan diastoliknya > $90 \mathrm{mmHg}$. Pasien ansietas akan mengalami peningkatan tekanan darah, akibat dari adanya peningkatan adrenalin, kondisi ini dapat membahayakan bagi pasien hipertensi. Oleh karena itu, pasien hipertensi yang mengalami ansietas memerlukan penanganan yang baik dalam menurunkan ansietasnya. (Pome dan Rizal, 2019)

Hipertensi merupakan suatu keadaan yang menyebabkan tekanan darah tinggi secara terus-menerus dimana tekanan sistolik lebih dari $140 \mathrm{mmHg}$, tekanan diastolik $90 \mathrm{mmHg}$ atau lebih. Hipertensi atau penyakit darah tinggi merupakan suatu keadaan peredaran darah meningkat secara kronis. Hal ini terjadi karena jantungbekerja lebih cepat memompa darah untuk memenuhi kebutuhan oksigen dan nutrisi di dalam tubuh (Koes Irianto, 2014).

Hipertensi juga merupakan faktor utama terjadinya gangguan kardiovaskular. Apabila tidak ditangani dengan baik dapat mengakibatkan gagal ginjal, stroke, dimensia, gagal jantung, infark miokard, gangguan penglihatan dan hipertensi (Andrian Patica N E- journal keperawatan volume 4 nomor 1, Mei 2016)

1. Jenis Hipertensi

Hipertensi dapat didiagnosa sebagai penyakit yang berdiri sendiri tetapi sering dijumpai dengan penyakit lain, misalnya arterioskeloris, obesitas, dan diabetes militus. Berdasarkan penyebabnya, hipertensi dapat dikelompokkan menjadi dua golongan yaitu (WHO, 2014) :

a. Hipertensi esensial atau hipertensi primer

Sebanyak 90-95 persen kasus hipertensi yang terjadi tidak diketahui dengan pasti apa penyebabnya. Para pakar menemukan hubungan antara riwayat keluarga penderita hipertensi (genetik) dengan resiko menderita penyakit ini. Selain itu juga para pakar menunjukan stres sebagai tertuduh utama, dan faktor lain yang mempengaruhinya. Faktor-faktor 
lain yang dapat dimasukkan dalam penyebab hipertensi jenis ini adalah lingkungan, kelainan metabolisme, intra seluler, dan faktor-faktor ynag meningkatkan resikonya seperti obesitas, merokok, konsumsi alkohol, dan kelainan darah. Hipertensi renal atau hipertensi sekunder

Pada 5-10 persen kasus sisanya, penyebab khususnya sudah diketahui, yaitu gangguan hormonal, penyakit diabetes, jantung, ginjal, penyakit pembuluh darah atau berhubungan dengan kehamilan. Kasus yang sering terjadi adalah karena tumor kelenjar adrenal. Garam dapur akan memperburuk resiko hipertensi tetapi bukan faktor penyebab.

Tabel 1. Klasifikasi Tekanan Darah Pada Orang Dewasa

\begin{tabular}{lcc}
\hline Kategori & $\begin{array}{c}\text { Sistolik } \\
\text { mmHg }\end{array}$ & $\begin{array}{c}\text { Diastolik } \\
\text { mmHg }\end{array}$ \\
\hline Normal & $<130$ & $<85$ \\
& $\mathrm{mmHg}$ & $\mathrm{mmHg}$ \\
Normal Tinggi & $130-139$ & $85-89$ \\
& $\mathrm{mmHg}$ & $\mathrm{mmHg}$ \\
Stadium 1 & $140-159$ & $90-99$ \\
(HipertensiRingan) & $\mathrm{mmHg}$ & $\mathrm{mmHg}$ \\
Stadium 2 & $160-179$ & $100-109$ \\
(HipertensiSedang) & $\mathrm{mmHg}$ & $\mathrm{mmHg}$ \\
Stadium 3 & $180-209$ & $110-119$ \\
(HipertensiBerat) & $\mathrm{mmHg}$ & $\mathrm{mmHg}$ \\
Stadium & 201 & 120 \\
(HipertensiSangatBeratatauMaligna) & $\mathrm{mmHg}$ & $\mathrm{mmHg}$ \\
& ataulebih & ataulebih
\end{tabular}

Sumber : Heniwati, 2008

2. Faktor-Faktor Yang Mempengaruhi Hipertensi

a. Faktor resiko yang tidak dapat dikontrol :

1) Jenis kelamin

Prevalensi terjadinya hipertensi pada pria dengan wanita. Wanita 
diketahui mempunyai tekanan darah lebih rendah dibandingkan pria ketika berusia 20-30 tahun. Tetapi akan mudah menyerang pada wanita ketika berumur 55 tahun,

sekitar $60 \%$ menderita hipertensi berpengaruh pada wanita. Halini dikaitkan dengan perubahan hormon pada wanita setelah menopause (Endang Triyanto, 2014).

2) Umur

Perubahan tekanan darah pada seseorang secara stabil akan berubah di usia 20-40 tahun. Setelah itu akan cenderung lebih meningkat secara cepat. Sehingga, semakin bertambah usia seseorang maka tekanan darah semakin meningkat. Jadi seorang lansia cenderung mempunyai tekanan darah lebih tinggi dibandingkan diusia muda (Endang Triyanto, 2014).

3) Keturunan (genetik)

Adanya faktor genetik tentu akan berpengaruh terhadap keluarga yang telah menderita hipertensi sebelumnya. Hal ini terjadi adanya peningkatan kadar sodium intraseluler dan rendahnya rasio antara potasium terhadap sodium individu sehingga pada orang tua cenderung beresiko lebih tinggi menderita hipertensi dua kali lebih besar dibandingan dengan orang yang tidak mempunyai riwayat keluarga dengan hipertensi (Buckman, 2010).

\section{4) Pendidikan}

Tingkat pendidikan secara tidak langsung mempengaruhi tekanan darah. Tingginya resiko hipertensi pada pendidikan yang rendah, kemungkinan kurangnya pengetahuan dalam menerima informasi oleh petugas kesehatan sehingga berdampak pada perilaku atau pola hidup sehat (Armilawaty, Amalia H, Amirudin R., 2007).

b. Faktor resiko hipertensi yang dapat dikontrol

1) Obesitas

Pada usia pertengahan dan usia lanjut, cenderung kurangnya melakukan aktivitas sehingga asupan kalori mengimbangi 
kebutuhan energi, sehingga akan terjadi peningkatan berat badan atau obesitas dan akan memperburuk kondisi (Anggara, F.H.D., \& N. Prayitno, 2013).

2) Kurang olahraga

Jika melakukan olahraga dengan teratur akan mudah untuk mengurangi peningkatan tekanan darah tinggi yang akan menurunkan tahanan perifer, sehigga melatih otot jantung untuk terbiasa melakuakn pekerjaan yang lebih berat karena adanya kondisi tertentu.

3) Kebiasaan merokok

Merokok dapat meningkatkan tekanan darah. Hal ini dikarenakan di dalam kandungan nikotik yang dapatmenyebabkan penyempitan pembuluh darah.

4) Konsumsi garam berlebihan

WHO merekomendasikan konsumsi garam yang dapat mengurangi peningkatan hipertensi. Kadar sodium yang direkomendasikan adalah tidak lebih dari $100 \mathrm{mmol}$ (sekitar 2,4 gram sodium atau 6 gram) (H. Hadi Martono Kris Pranaka, 20142015).

5) Minum alkohol

Ketika mengonsumsi alkohol secara berlebihan akan menyebabkan peningkatan tekanan darah yang tergolong parah karena dapat menyebabkan darah di otak tersumbat dan menyebabkan stroke.

6) Minum kopi

Satu cangkir kopi mengandung kafein 75-200 mg, dimana dalam satu cangkir kopi dapat meningkatakan tekanan darah 5- 10 $\mathrm{mmHg}$.

7) Kecemasan

Kecemasan akan menimbulkan stimulus simpatis yang akan meningkatkan frekuensi jantung, curah jantung dan resistensi vaskuler, efek samping ini akan meningkatkan tekanan darah. Kecemasan atau stress meningkatkan tekanan darah sebesar 30 
mmHg. Jika individu meras cemas pada masalah yang di hadapinya maka hipertensi akan terjadi pada dirinya. Hal ini dikarenakan kecemasan yang berulang-ulang akan mempengaruhi detak jantung semakin cepat sehingga jantung memompa darah keseluruh tubuh akan semakin cepat.

\section{Konsep Kecemasan}

\section{Defenisi Ansietas}

Kecemasan merupakan suatu keadaan perasaan gelisah, ketidaktentuan, ada rasa takut dari kenyataan atau persepsi ancaman sumber aktual yang tidak diketahui masalahnya (Pardede \& Simangunsong, 2020). Kecemasan merupakan suatu respon psikologis maupun fisiologis individu terhadap suatu keadaan yang tidak menyenangkan, atau reaksi atas situasi yang dianggap mengancam (Hulu \& Pardede, 2016).

Kecemasan adalah pengalaman subjektif dari ketegangan mental yang mengganggu sebagai reaksi umum dan ketidakmampuan untuk menghadapi masalah atau adanya rasa tidak aman. Perasaan tidak menyenangkan umumnya menimbulkan gejala fisiologis (seperti gemetar, berkeringat, detak jantung meningkat, dll) dan gejala psikologis seperti panik, tegang, bingung, tidak dapat berkonsentrasi, dll ( Pardede, Simanjunt ak, \& Manalu 2020).

Kecemasan (anxiety) merupakan perasaan takut yang tidak jelas penyebabnya dan tidak didukung oleh situasi yang ada. Kecemasan dapat dirasakan oleh setiap orang jika mengalami tekanan dan perasaan mendalam yang menyebabkan masalah psikiatrik dan dapat berkembang dalam jangka waktu lama. (Marbun, Pardede \& Perkasa, 2019).

Menurut Pardede, Sitepu \& Saragih, (2018), dampak dari kecemasan berat pada pasien preoperasi tidak menutup kemungkinan tindakan pembedahan tidak bisa dilakukan, karena pasien yang cemas sebelum dilakukan operasi akan menyebabkan tekanan darah meningkat, sehingga ketika dilakukan tindakan pembedahan akan mempersulit dalammenghentikan perdarahan, dan bahkan setelah tindakan pembedahan pun akan menghambat penyembuhan. 
Kecemasan yang terjadi tidak saja dialami oleh seorang pasien tetapi dapat juga dialami oleh perawat karena perawat terkadang cemas ketika berhadapan dengan pasien dan keluarga pasien Pardede, Keliat, Damanik, \& Gulo (2020).

\section{Etiologi}

Meski penyebab ansietas belum sepenuhnya diketahui, namun gangguan keseimbangan neurotransmitter dalam otak dapat menimbulkan ansietas pada diri seseorang. Faktor genetik juga merupakan faktor yang dapat juga menimbulkan gangguan ini, ansietas terjadi ketika seseorang mengalami kesulitan menghadapi situa si, masalah dan tujuan hidup (Videbeck, 2018). Setiap individu menghadapi stress dengan cara berbeda-beda, seseorang dapat tumbuh dalam situasi yang dapa menimbulkan stress berat pada orang lain adapun faktor-faktornya yang mempengaruhi ansietas adalah :

1. Faktor predisposisi

Berbagai teori yang dikembangkan untuk menjelaskan penyebab ansietas adalah:

a. Teori psikionalitik

Ansietas merupakan konflik emosional antara dua elemen yaitu ide, ego dan super ego. Ide melambangkan dorongan insting, ego digambarkan sebagai mediator antara ide dan super ego mencerminkan hati nurani seseorang dan dikendalikan oleh norma-norma budaya seseorang, ansietas berfungsi untuk memperingatkan ego tenang suatu budaya yang perlu segera diatasi

b. Teori interpersonal

Ansietas terjadi dari ketakutan akan penolakan interpersonal berhubungan juga dengan trauma masa perkembangan seperti kehilangan, perpisahan. Individu dengan harga diri rendah biasanya sangat mengalami ansietas berat

c. Teori perilaku

Ansietas merupakan produk frustasi yaitu segala sesuatu yang yang menggangu kemampuan seseorang untuk mencapai tujuan yang diharapkan

d. Kajian biologis 
Kajian biologis menunjukan bahwa otak mengandung reseptor khusus untuk benzodiazepin, obat-obatan yang meningkatan neuroregulator yang berperan penting dalam mekanisme biologis yang berhubungan dengan ansietas (Stuart, Keliat \& Pasaribu, 2016)

2. Faktor presipitasi

Bersumber dari eksternal dan internal seperti :

a. Ancaman terhadap integritas fisik meliputi ketidakmampuan fisiologis atau menurunnya kemampuan melaksanakan fungsi kehidpan seharihari(Stuart, Keliat \& Pasaribu, 2016)

b. Ancaman terhadap sistem diri dapat membahayakan identitas harga diri dan integritas fungsi sosial. (Stuart, Keliat \& Pasaribu, 2016)

3. Perilaku

Ansietas dapat diekspresikan langsung melalui perubahan fisiologis dan perilaku secara tidak langsung timbulnya gejala atau mekanisme koping dalam meningkat sejalan dengan peningkatan ansietas

\section{Tingkat Ansietas}

1. Ansietas Ringan

Ansietas ringan berhubungan dengan ketengan akan peristiwa kehidupan sehari-hari. Pada tingkat ini laangan persepsi melebar dan individu terdorong untuk belajar yang akan menghasilkan pertumbuhan kreatifitas. (Bulechek, 2016).

a. Respon fisiologis

1. Sesekali napas pendek

2. Nadi dan tekanan darah naik

3. Gejala ringan pada lambung

4. Muka berkerut dan bibir bergetar

b. Respon kognitif

1. Lapang persepsi melebar

2. Mampu menerima rangsangan yang kompleks

3. Konsentrasi pada maslah

4. Menejlaskan masalah secara efektif

c. Respon perilaku dan emosi

1. Tidak dapat duduk tenang 
2. Tremor halus pada tangan

3. Suara kadang-kadang meninggi

2. Ansietas sedang

Pada tingkat ini lapangan persepsi terhadap lingkugan menurun. Individu lebih memfokuskan hal-hal penting dan mengenyampingkan hal-hal lain (Bulechek, 2016).

a. Respon fisiologis

1. Nadi (ekstra systole) dan tekanan darah naik

2. Mulut kering

3. Anorexia

4. Diare/konstipasi

5. Gelisah

b. Respon kognitif

1. Lapang persepsi menyempit

2. Rangsang luar tidak mampu diterima

3. Berfokus pada apa yang menjadi perhatian

c. Respon perilaku dan emosi

1. Gerakan tersentak-sentak (meremas tangan)

2. Bicara banyak dan lebih cepat

3. Susah tidur

4. Perasaan tidak aman

3. Ansietas berat

Pada ansietas berat lapangan persepsi menjadi sangat sempit, individu cenderung memikirkan hal yang kecil saja dan mengabaikan hal lain,individu tidak mampu lagi berpikir realistis dan membutuhkan pengarahan untuk memusatkan perhatian pada area lain (Bulechek, 2016).

a. Respon fisiologi

1) Sering nafas pendek Nadi dan tekanan darah naik

2) Berkeringat dan sakit kepala

3) Penglihatan kabur

4) Ketegangan

b. Respon kognif

1. Lapang persepsi sangat sempit

2. Tidak mampu menyelesaikan masalah 
3. Respon perilaku dan emosi

4. Perasaan ancam meningkat

2. verbialisasi cepat

5. Blocking

\section{Mekanisme Koping}

Ketika pasien mengalami ansietas, individu menggunakan bermacammacammekanisme koping untuk mencoba mengatasinya. Dalam bentuk ringan ansietas bentuk ringan ansietas dapat di atasi dengan menangis, tertawa, tidur, olahraga atau merokok. Bila terjadi ansietas berat sampai panik akan terjadi ketidakmampuan mengatasi ansietas secara konstruktif merupakan penyebab utama perilaku yang patologis, individu akan menggunakan energy yang lebih besar untuk dapat mengatasi ancaman tersebut.

Mekanisme koping untuk mengatasi ansietas adalah:

1. Reaksi yang berorientasi pada tugas (task oriented reaction) Merupakan pemecahan masalah secara sadar yang digunakan untuk menanggulangi ancaman stressor yang ada secara realistis yaitu:

a. Perilaku menyerang (Agresif) Biasanya digunakan individu untuk mengatasi rintangan agar memenuhi kebutuhan.

b. Perilaku menarik diri Digunakan untuk menghilangkan sumber ancaman baik secara fisik maupun psikologis.

c. Perilaku kompromi Digunakan untuk merubah tujuan yang akan dilakukan atau mengorbankan kebutuhan personal untuk mencapai tujuan.

2. Mekanisme pertahanan ego (Ego oriented reaction) Mekanisme ini membantu mengatasi ansietas ringan dan sedang yang digunakan untuk melindungi diri dan dilakukan secara sadar untuk mempertahankan keseimbangan. Mekanisme pertahanan ego:

a. Disosiasi adalah pemisahan dari proses mental atau perilaku dari kesadaran atau identitasnya.

b. Identifikasi (identification) adalah proses dimana seseorang untuk menjadi yang ia kagumi berupaya dengan mengambil/meniru pikiranpikiran, perilaku dan selera orang tersebut. 
c. Intelektualisasi (intellectualization) adalah penggunaan logika dan alasan yang berlebihan untuk menghindari pengalaman yang mengganggu perasaannya.

d. Introjeksin (introjection) adalah suatu jenis identifikasi yang dimana seseorang mengambil dan melebur nilai-nilai dan kualitas seseorang atau suatu kelompok kedalam struktur egonya sendiri, berupa hati nurani, contohnya rasa benci atau kecewa terhadap kematian orang yang dicintai, dialihkan dengan cara menyalahkan diri sendiri.

e. Kompensasi adalah proses dimana seseorang memperbaiki penurunan citra diri dengan secara tegas menonjolkan keistimewaan/kelebihan yang dimilikinya. Penyangkalan (Denial) adalah menyatakan ketidaksetujuan terhadap realitas dengan mengingkari realitas tersebut. Mekanisme pertahanan ini adalah penting, sederhana, primitif.

f. Pemindahan (displacement) adalah pengalihan emosi yang semula ditujukan pada seseorang/benda kepada orang lain/benda lain yang biasanya netral atau kurang mengancam dirinya.

g. Isolasi adalah pemisahan unsur emosional dari suatu pikiran yang menggangu dapat bersifat sementara atau berjangka lama.

h. Proyeksi adalah pengalihan buah pikiran atau impuls pada diri sendiri kepada orang lain terutama keinginan, perasaan emosional dan motivasi yang tidak dapat ditoleransi.

i. Rasionalisasi adalah mengemukakan penjelasan yang tampak logis dan dapat diterima masyarakat untuk membenarkan perasaan perilaku dan motif yang tidak dapat diterima.

j. Reaksi formasi adalah pengembangan sikap dan pola perilaku yang ia sadari yang bertentangan dengan apa yang sebenarnya ia rasakan atau ingin dilakukan.

k. Regresi adalah kemunduran akibat stress terhadap perilaku dan merupakan ciri khas dari suatu taraf perkembangan yang lebih dini.

1. Represi adalah pengenyampingkan secara tidak sadar tentang-tentang pikiran, ingatan yang menyakitkan atau bertentangan ,dari kesadaran seseorang merupakan pertahanan ego yang primer yang cenderung diperkuat oleh mekanisme lain. 
BAB 3

TINJAUAN KASUS

\begin{tabular}{|l|l|}
\hline Nama : Tn. A & Kondisi saat MRS: Pasien mengeluh nyeri \\
Usia : 50 tahun & dan merasa cemas karena penyakit yang di \\
Tahun no reg : - & alaminya, tekanan darah tinggi \\
Ruangan : - & Kondisi saat ini : \\
Tgl masuk rs: - & Tn. A mengeluh badannya terasa lemas, \\
Tgl pengkajian : 16 oktober 2021 & nyeri, pusing sehingga Tn. A tidak mampu \\
Alamat : jl. Bakti luhur gang rahayu no. 74 & melakukan aktivitas seperti biasanya, hingga \\
& membuat Tn. A takut dan gelisah dan tidak \\
\end{tabular}




\begin{tabular}{|c|c|c|c|c|}
\hline \multirow[t]{2}{*}{ Faktor predisposisi } & \multicolumn{3}{|l|}{ Faktor presipitasi } & \multirow[t]{2}{*}{ STRESSOR } \\
\hline & Nature & Origin & Number \& Timing & \\
\hline $\begin{array}{l}\text { Biologis: } \\
\begin{array}{l}\text { 1. Hipertensi } \\
\text { 2. Tn. A menderita Hipertensi sejak } 2 \\
\text { tahun lalu } \\
\text { 3. Tn. A sering mengkonsumsi makanan } \\
\quad \text { yang asin }\end{array}\end{array}$ & 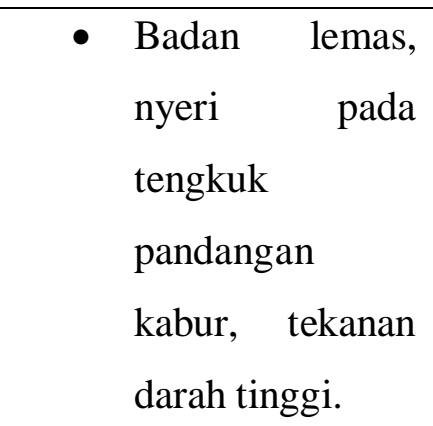 & Internal & Sejak 2 tahun yang lalu & - Hipertensi \\
\hline $\begin{array}{l}\text { Psikologis : } \\
\text { 1. Tn. A memiliki kepribadian yang } \\
\text { terbuka setiap ada masalah akan } \\
\text { dibicarakan dengan suaminya } \\
\text { 2. Tn. A merasa pening dan napas } \\
\text { pendek } \\
\text { 3. Tn. A merasa gelisah dengan kondisi } \\
\text { penyakit nya dan keadaaan yang } \\
\text { lemah karna sudah menua }\end{array}$ & $\begin{array}{l}\text { - Gelisah, jantung } \\
\text { berdebar, tremor } \\
\text { - Cemas dengan } \\
\text { penyakit nya } \\
\text { dan juga umur } \\
\text { yang semakin } \\
\text { menua }\end{array}$ & Internal & Sejak terkena hipertensi & $\begin{array}{l}\text { - Ansietas, } \\
\text { khawatir dan } \\
\text { takut }\end{array}$ \\
\hline $\begin{array}{l}\text { Sosiocultural : } \\
\text { 1. Tn. A seorang laki-laki umur } 50\end{array}$ & & & & \\
\hline
\end{tabular}




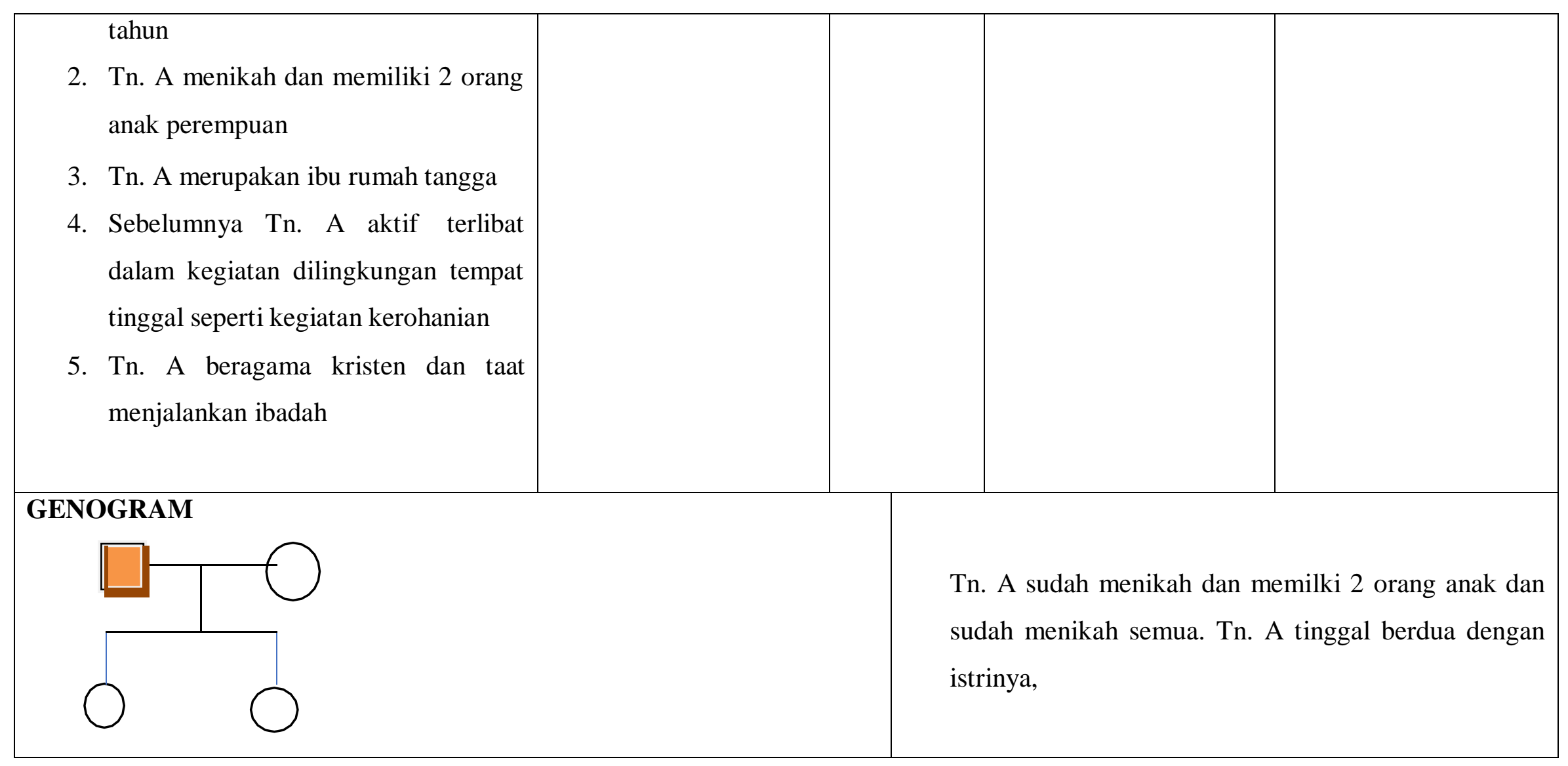


PENILAIAN (RESPON)TERHADAP STRESSOR

\begin{tabular}{|c|c|c|c|c|c|c|}
\hline STRESSOR & KOGNITIF & AFEKTIF & FISIOLOGIS & PERILAKU & SOSIAL & $\begin{array}{l}\text { DIAGNOSA } \\
\text { KEPERAWAT } \\
\text { AN }\end{array}$ \\
\hline $\begin{array}{l}\text { BIOLOGIS } \\
\text { - (Hipertensi) }\end{array}$ & 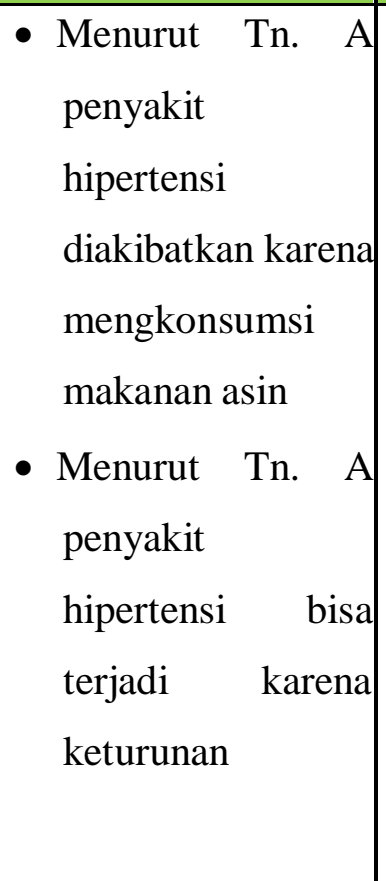 & $\begin{array}{l}\text { - Tn. A merasa } \\
\text { takut dan } \\
\text { gelisah karena } \\
\text { penyakitnya } \\
\text { serta umurnya } \\
\text { semakin } \\
\text { menua }\end{array}$ & $\begin{array}{l}\text { - } \text { Tekanan Darah naik } \\
\text { - Sering Berkeringat } \\
\text { - } \text { Rasa sakit kepala } \\
\text { - } \text { Sulit tidur } \\
\text { - penglihatan kabur } \\
\text { - } \text { Tn. A tampak lemas } \\
\text { - Pemeriksaan TTV } \\
\text { TD: } 180 / 100 \\
\text { mmhg } \\
\mathrm{N}: 90 \text { x / menit } \\
\text { P : } 24 \text { x / menit } \\
\text { S: } 36.5^{\circ} \mathrm{C}\end{array}$ & 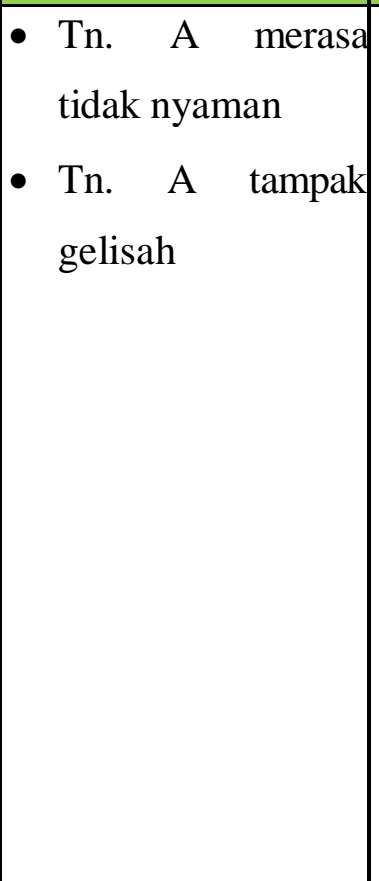 & $\begin{array}{l}\text { - Tn. A ketempat } \\
\text { pelayanan } \\
\text { kesehatan dan } \\
\text { menggunakan } \\
\text { fasilitas } \\
\text { kesehatan untuk } \\
\text { mendapatkan } \\
\text { perawatan. }\end{array}$ & - Ansietas \\
\hline $\begin{array}{l}\text { PSIKOLOGIS } \\
\text { - Sedih, cemas, } \\
\text { dengan kondisi } \\
\text { penyakit dan }\end{array}$ & $\begin{array}{l}\text { - Tn. A menyadari } \\
\text { bahwa badannya } \\
\text { menjadi lemah, } \\
\text { gemetaran dan }\end{array}$ & $\begin{array}{l}\text { - Merasa takut } \\
\text { dengan } \\
\text { penyakitnya } \\
\text { yang akan }\end{array}$ & $\begin{array}{l}\text { - } \text { rasa sakit kepala } \\
\text { - tengkuk dan bahu } \\
\text { terasa tegang } \\
\text { - berkeringat banyak }\end{array}$ & $\begin{array}{|ll|}\text { - } & \text { Tampak cemas } \\
\text { dan tidak tenang } \\
\text { - Tn. A tampak } \\
\text { gelisah }\end{array}$ & 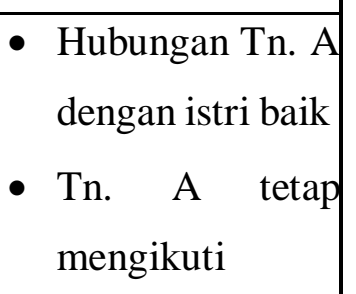 & \\
\hline
\end{tabular}




\begin{tabular}{|c|c|c|c|c|c|}
\hline $\begin{array}{l}\text { pengobatan serta } \\
\text { Perawatannya }\end{array}$ & $\begin{array}{l}\text { tengkuk nyeri serta } \\
\text { jantung berdebar } \\
\text { kencang } \\
\text { merupakan } \\
\text { dampak dari } \\
\text { penyakit yang } \\
\text { dideritanya }\end{array}$ & $\begin{array}{l}\text { membuat dia } \\
\text { semakin } \\
\text { lemah dan } \\
\text { tidak dapat } \\
\text { beraktivitas }\end{array}$ & $\begin{array}{l}\text { - } \text { Tn. A tampak lemas } \\
\text { - Wajah Tn. A tampak } \\
\text { pucat } \\
\text { - Pemeriksaan TTV } \\
\text { TD: } 180 / 100 \\
\text { mmhg } \\
\text { N : } 90 \text { x / menit } \\
\text { P : } 24 \times \text { x menit } \\
\text { S: } 36.5^{\circ} \mathrm{C}\end{array}$ & 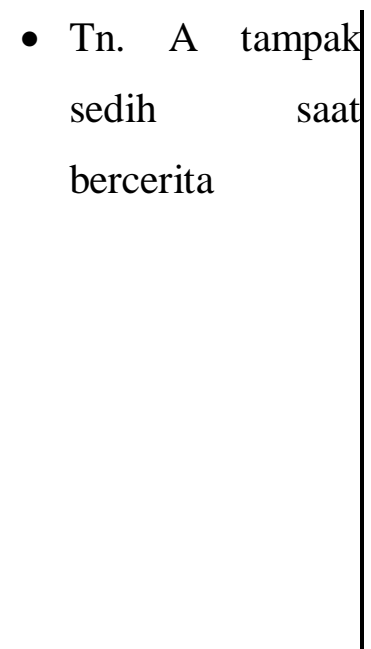 & $\begin{array}{l}\text { program } \\
\text { pengobatan yang } \\
\text { diberikan } \\
\text { kepadanya }\end{array}$ \\
\hline 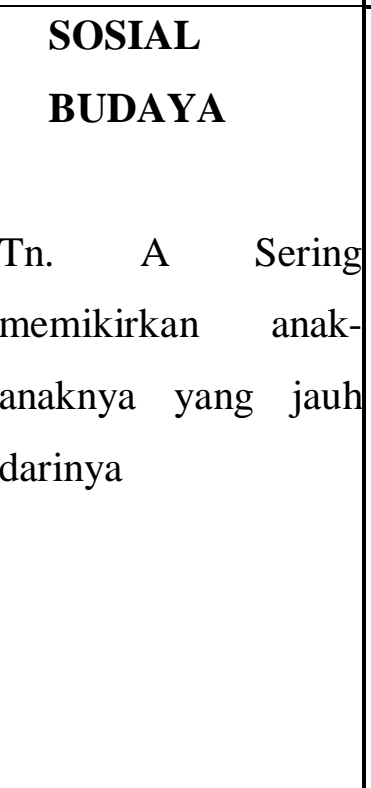 & $\begin{array}{l}\text { - Tn. A merasa tidak } \\
\text { berdaya dengan } \\
\text { keadaannya } \\
\text { sekarang tidak bisa } \\
\text { bekerja dan } \\
\text { beraktivitas berat } \\
\text { - merasa } \\
\text { Kasihan } \\
\text { kepada istri } \\
\text { yang harus } \\
\text { menjaga dan }\end{array}$ & 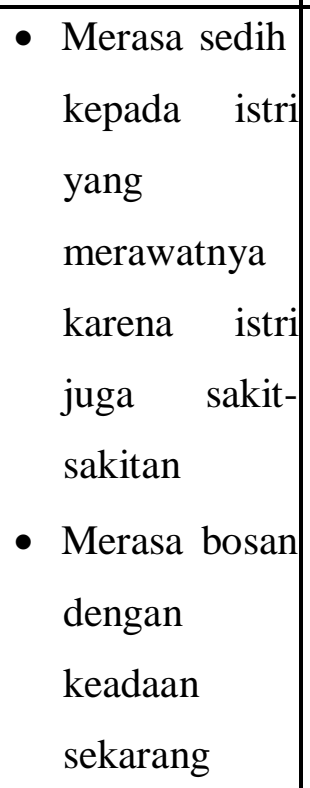 & $\begin{array}{l}\text { - } \text { Sakit kepala } \\
\text { - } \text { berkeringat banyak } \\
\text { - } \text { tengkuk dan Bahu } \\
\text { terasa tegang } \\
\text { - Tn. A tampak lemas }\end{array}$ & 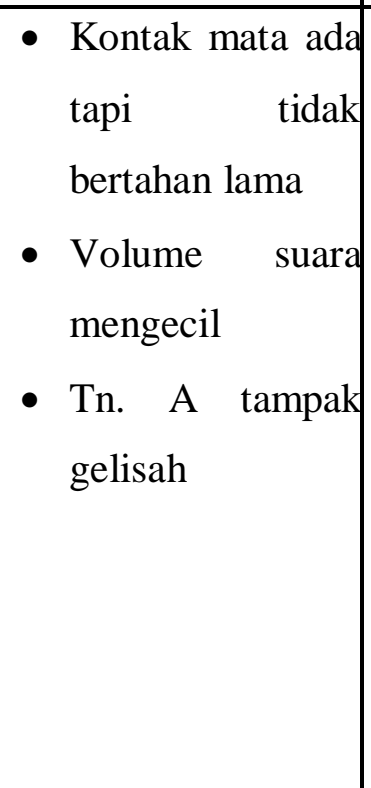 & $\begin{array}{l}\text { - Hubungan Tn. } \\
\text { A dengan istri } \\
\text { baik } \\
\text { - } \text { hubungan Tn. } \\
\text { A dengan anak- } \\
\text { anaknya baik } \\
\text { - Tn. A tetap } \\
\text { mengikuti } \\
\text { program } \\
\text { pengobatan }\end{array}$ \\
\hline
\end{tabular}




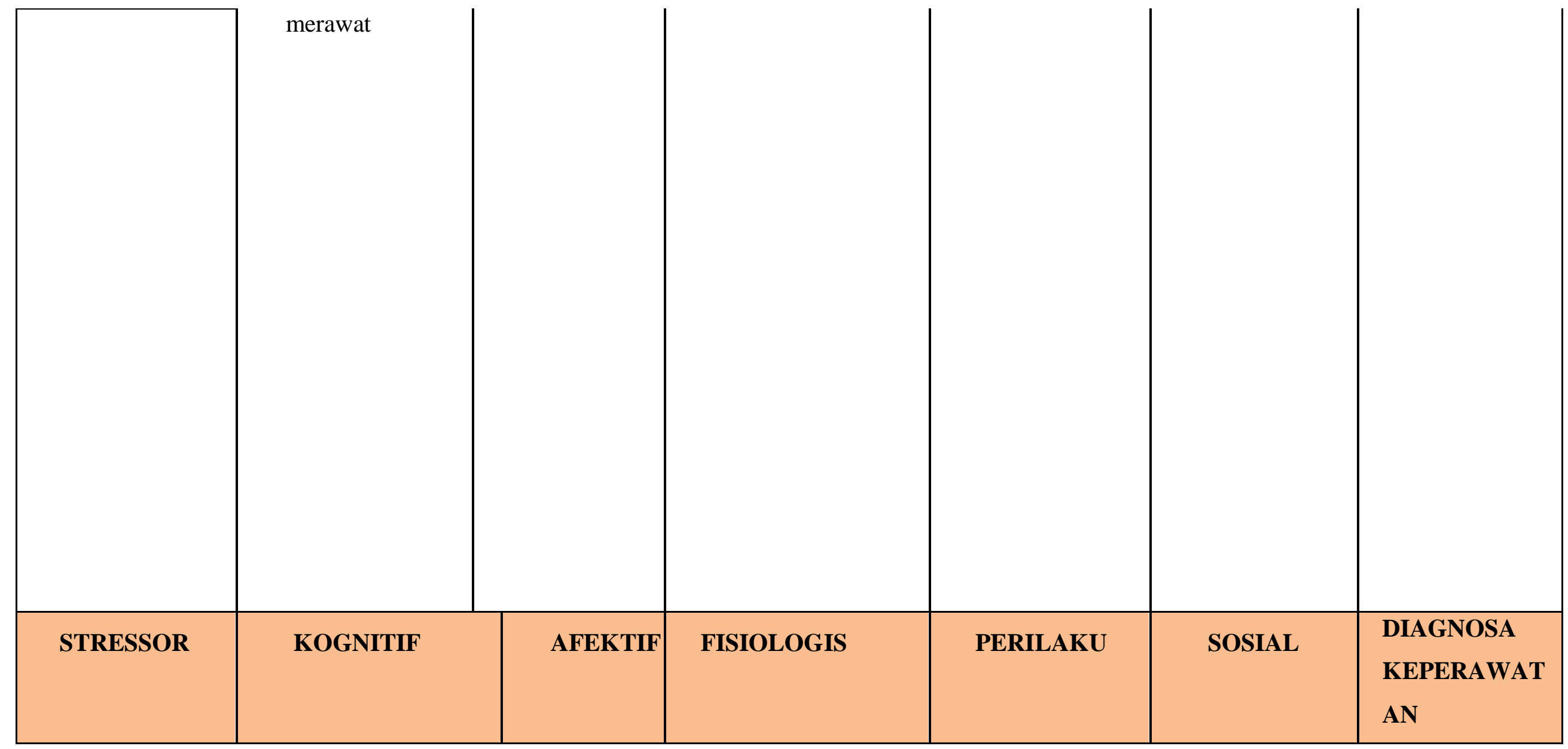




\begin{tabular}{|c|c|c|c|c|c|c|}
\hline $\begin{array}{l}\text { Biologi : } \\
\text { Stroke Hemoragik }\end{array}$ & 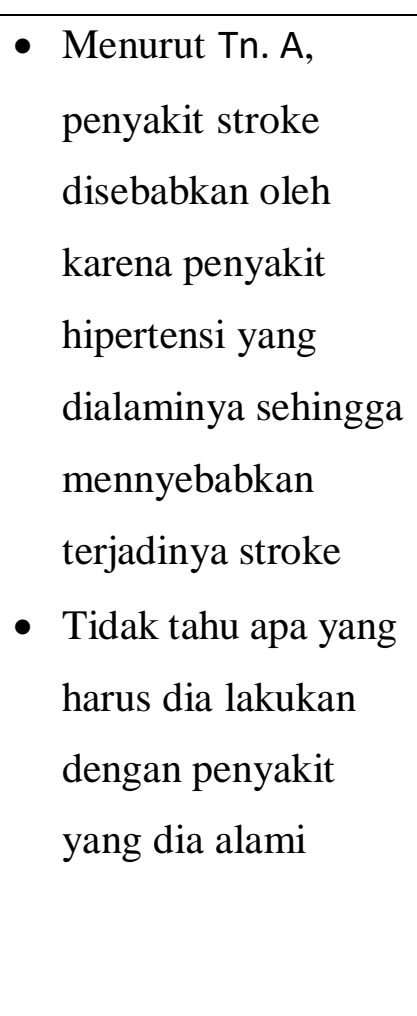 & $\begin{array}{l}\text { - Tn. A } \\
\text { Marah dan } \\
\text { bingung } \\
\text { dengan } \\
\text { penyakit } \\
\text { yang dia } \\
\text { alami } \\
\text { - Tn. A } \\
\text { Merasa } \\
\text { tertekan } \\
\text { terhadap } \\
\text { penurunan } \\
\text { fisik yang } \\
\text { dialaminya }\end{array}$ & 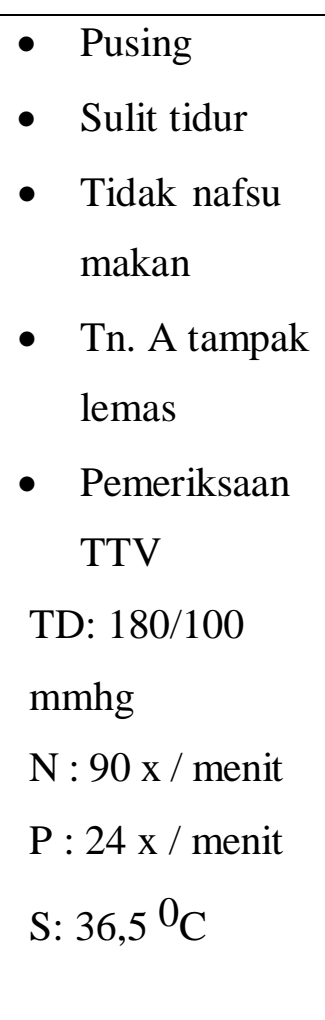 & $\begin{array}{l}\text { - Ketergantungan } \\
\text { terhadap orang } \\
\text { lain } \\
\text { - Gelisah }\end{array}$ & $\begin{array}{l}\text { 1. mampu } \\
\text { mengungkap } \\
\text { kan } \\
\text { perasaanny } \\
\text { 2. mampu } \\
\text { bersosialisasi } \\
\text { dengan orang } \\
\text { di sekitar }\end{array}$ & Ketidakberdayaan \\
\hline $\begin{array}{l}\text { Psikologis : } \\
\text { Tidak dapat } \\
\text { menjalankan } \\
\text { aktivitas seperti } \\
\text { biasa, malu, } \\
\text { ketergantungan } \\
\text { kepada keluarga }\end{array}$ & $\begin{array}{l}\text { Menurut Tn. A, } \\
\text { penyakit stroke } \\
\text { disebabkan oleh } \\
\text { karena penyakit } \\
\text { hipertensi yang } \\
\text { dialaminya sehingga } \\
\text { menyebabkan }\end{array}$ & $\begin{array}{l}\text { - Tn. A } \\
\text { Marah dan } \\
\text { bingung } \\
\text { dengan } \\
\text { penyakit } \\
\text { yang } \\
\text { dialami }\end{array}$ & $\begin{array}{ll}\text { - } & \text { Pusing } \\
\text { - } & \text { Sulit tidur } \\
\text { - } & \text { Tidak nafsu } \\
& \text { makan } \\
\text { - } & \text { Tn. A tampak } \\
\text { - } & \text { Pemas } \\
\text { - Pemeriksaan }\end{array}$ & $\begin{array}{l}\text { - Ketergantungan } \\
\text { terhadap orang } \\
\text { lain } \\
\text { - Gelisah }\end{array}$ & & \\
\hline
\end{tabular}




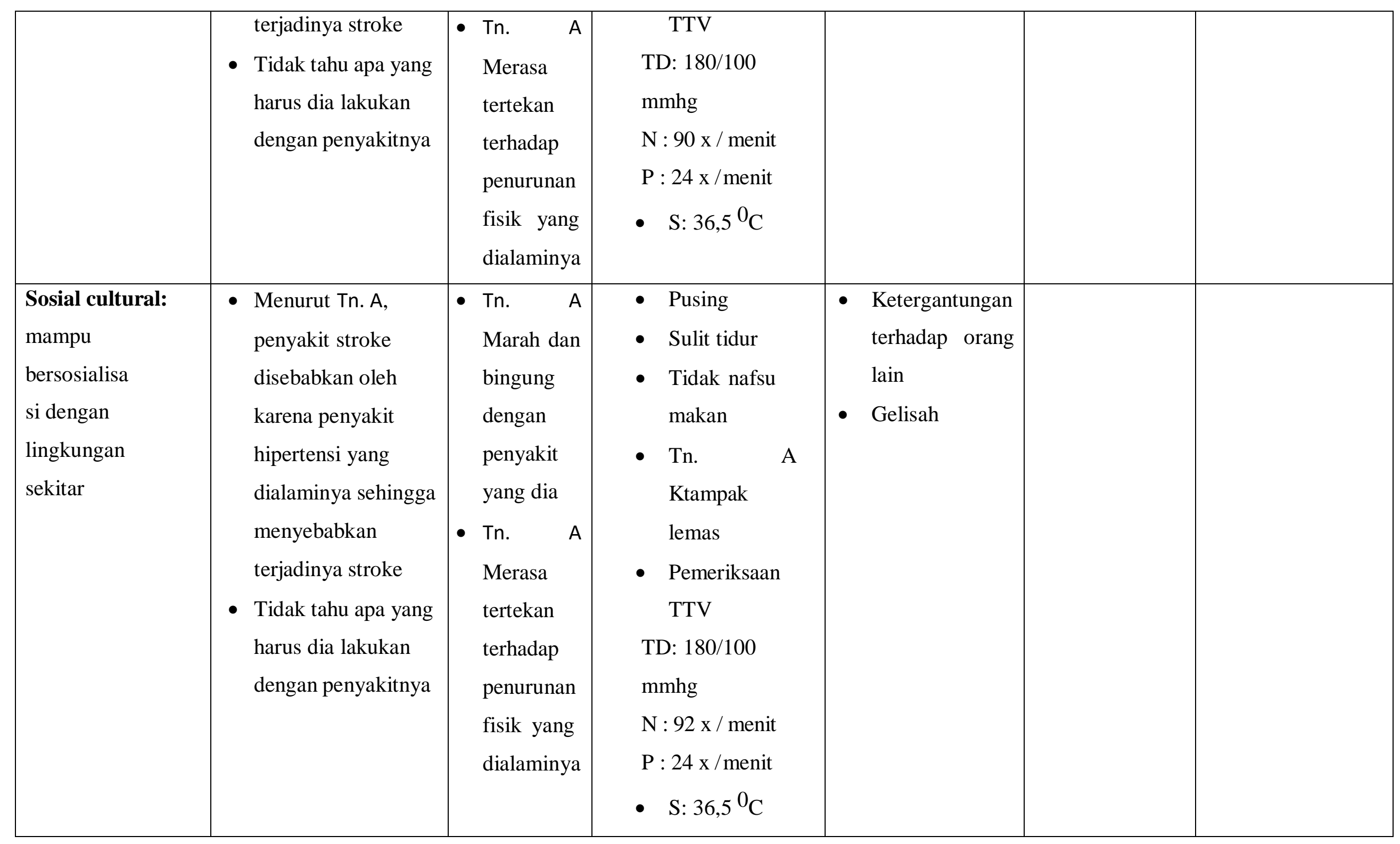




\begin{tabular}{|c|c|c|c|c|c|c|}
\hline $\begin{array}{l}\text { Spritual : } \\
\text { Menjalankan } \\
\text { ibadah seperti biasa } \\
\text { dan selalu } \\
\text { menjalankan } \\
\text { ibadah }\end{array}$ & 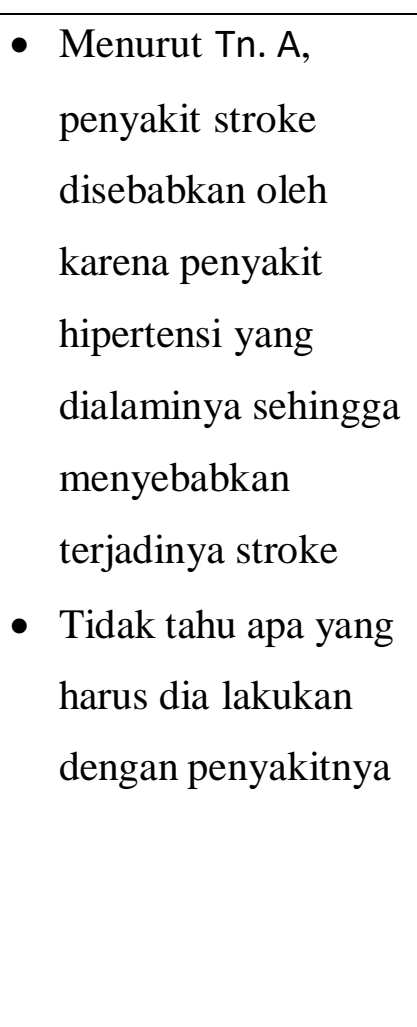 & $\begin{array}{l}\text { - } \text { Tn. A } \\
\text { Marah dan } \\
\text { bingung } \\
\text { dengan } \\
\text { penyakit } \\
\text { yang dia } \\
\text { - Tn. A } \\
\text { Merasa } \\
\text { tertekan } \\
\text { terhadap } \\
\text { penurunan } \\
\text { fisik yang } \\
\text { dialaminya }\end{array}$ & $\begin{array}{ll}\text { - } & \text { Pusing } \\
\text { - } & \text { Sulit tidur } \\
\text { - } & \text { Tidak nafsu } \\
& \text { makan } \\
\text { - } & \text { Tn. } \\
& \text { Ktampak } \\
& \text { lemas } \\
\text { - } & \text { Pemeriksaan } \\
& \text { TTV } \\
\text { TD: } 180 / 100 \\
\text { mmhg } \\
\text { N : } 90 \text { x / menit } \\
\text { P : } 24 \text { x / menit } \\
\text { - } \quad \text { : } 36,5{ }^{0} \mathrm{C}\end{array}$ & $\begin{array}{l}\text { - } \text { Ketergantungan } \\
\text { terhadap orang } \\
\text { lain } \\
\text { - Gelisah }\end{array}$ & & \\
\hline STRESSOR & KOGNITIF & AFEKTIF & FISIOLOGIS & PERILAKU & SOSIAL & $\begin{array}{l}\text { DIAGNOSA } \\
\text { KEPERAWATA } \\
\mathbf{N}\end{array}$ \\
\hline
\end{tabular}




\begin{tabular}{|c|c|c|c|c|c|c|}
\hline $\begin{array}{l}\text { Biologi : } \\
\text { Hipertensi }\end{array}$ & $\begin{array}{l}\text { - } \text { Menurut Tn. A, } \\
\text { penyakit Hipertensi } \\
\text { disebabkan oleh } \\
\text { makanan asin } \\
\text { - } \text { Tidak tahu apa yang } \\
\text { harus dia lakukan } \\
\text { dengan penyakitnya }\end{array}$ & $\begin{array}{l}\text { - Tn. A } \\
\text { Marah dan } \\
\text { bingung } \\
\text { dengan } \\
\text { penyakit } \\
\text { yang dia } \\
\text { - Tn. A } \\
\text { Merasa } \\
\text { tertekan } \\
\text { terhadap } \\
\text { penurunan } \\
\text { fisik yang } \\
\text { dialaminya }\end{array}$ & 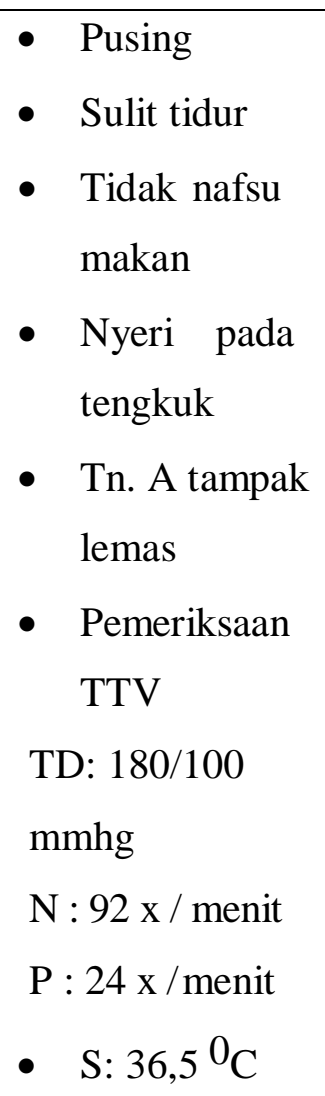 & $\begin{array}{l}\text { - } \text { Ketergantungan } \\
\text { terhadap orang } \\
\text { lain } \\
\text { - Gelisah }\end{array}$ & $\begin{array}{l}\text { 1. mampu } \\
\text { mengungkap } \\
\text { kan } \\
\text { perasaanny } \\
\text { 2. mampu } \\
\text { bersosialisasi } \\
\text { dengan orang } \\
\text { sekitar }\end{array}$ & $\begin{array}{l}\text { Penampilan peran } \\
\text { tidak efektif }\end{array}$ \\
\hline $\begin{array}{l}\text { Psikologis : } \\
\text { Tidak dapat } \\
\text { menjalanka } \\
\text { n aktivitas, } \\
\text { malu, } \\
\text { ketergantun }\end{array}$ & $\begin{array}{l}\text { - } \text { Menurut Tn. A, } \\
\text { penyakit Hipertensi } \\
\text { disebabkan oleh } \\
\text { makanan asin } \\
\\
\text { - Tidak tahu apa yang }\end{array}$ & $\begin{array}{l}\text { - Tn. A } \\
\text { Marah dan } \\
\text { bingung } \\
\text { dengan } \\
\text { penyakit } \\
\text { yang dia }\end{array}$ & $\begin{array}{ll}\text { - } & \text { Pusing } \\
\text { - } & \text { Sulit tidur } \\
\text { - } & \text { Tidak nafsu } \\
& \text { makan } \\
\text { - } & \text { Ny.L } \\
& \text { Ktampak }\end{array}$ & $\begin{array}{l}\text { - Ketergantungan } \\
\text { terhadap orang } \\
\text { lain } \\
\text { - Gelisah }\end{array}$ & & \\
\hline
\end{tabular}




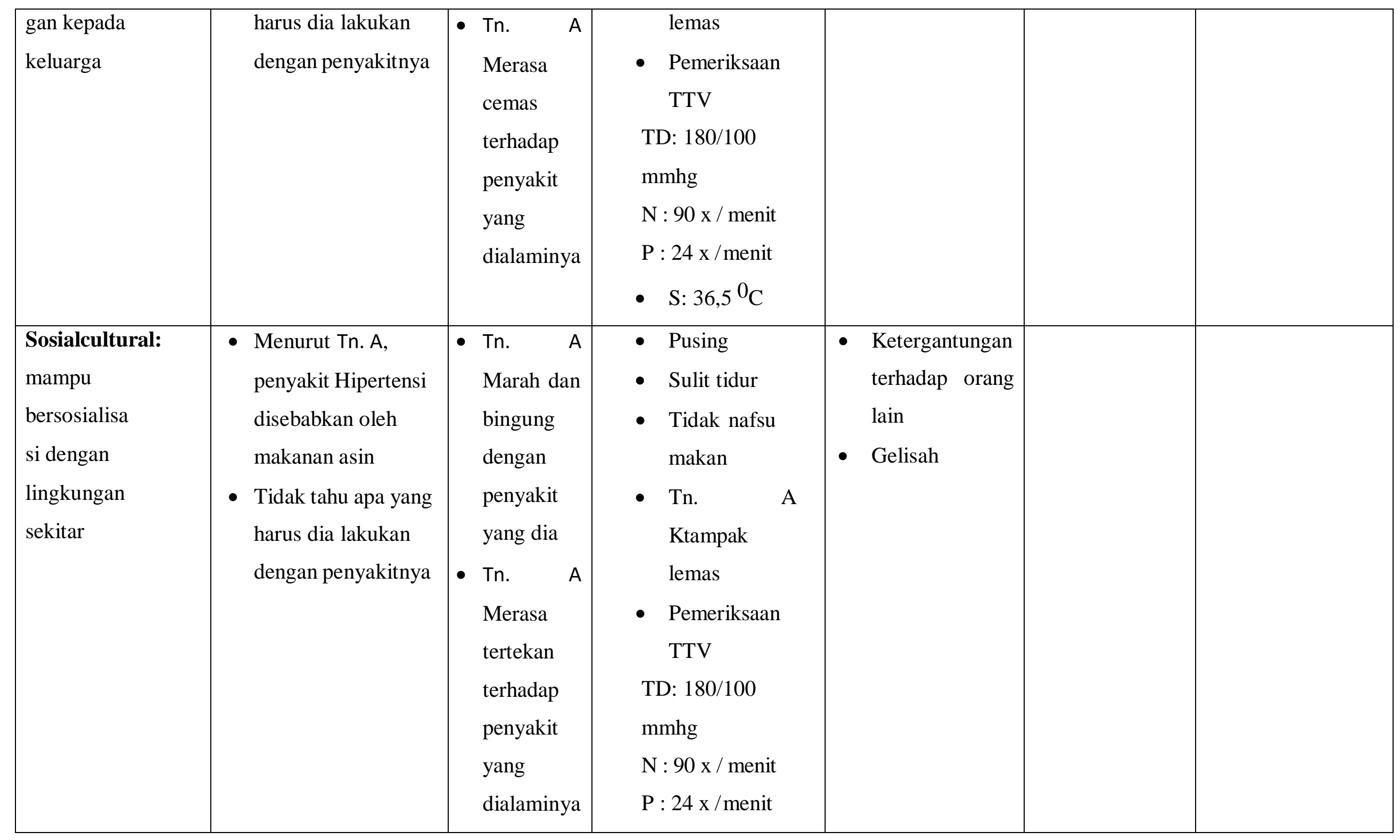




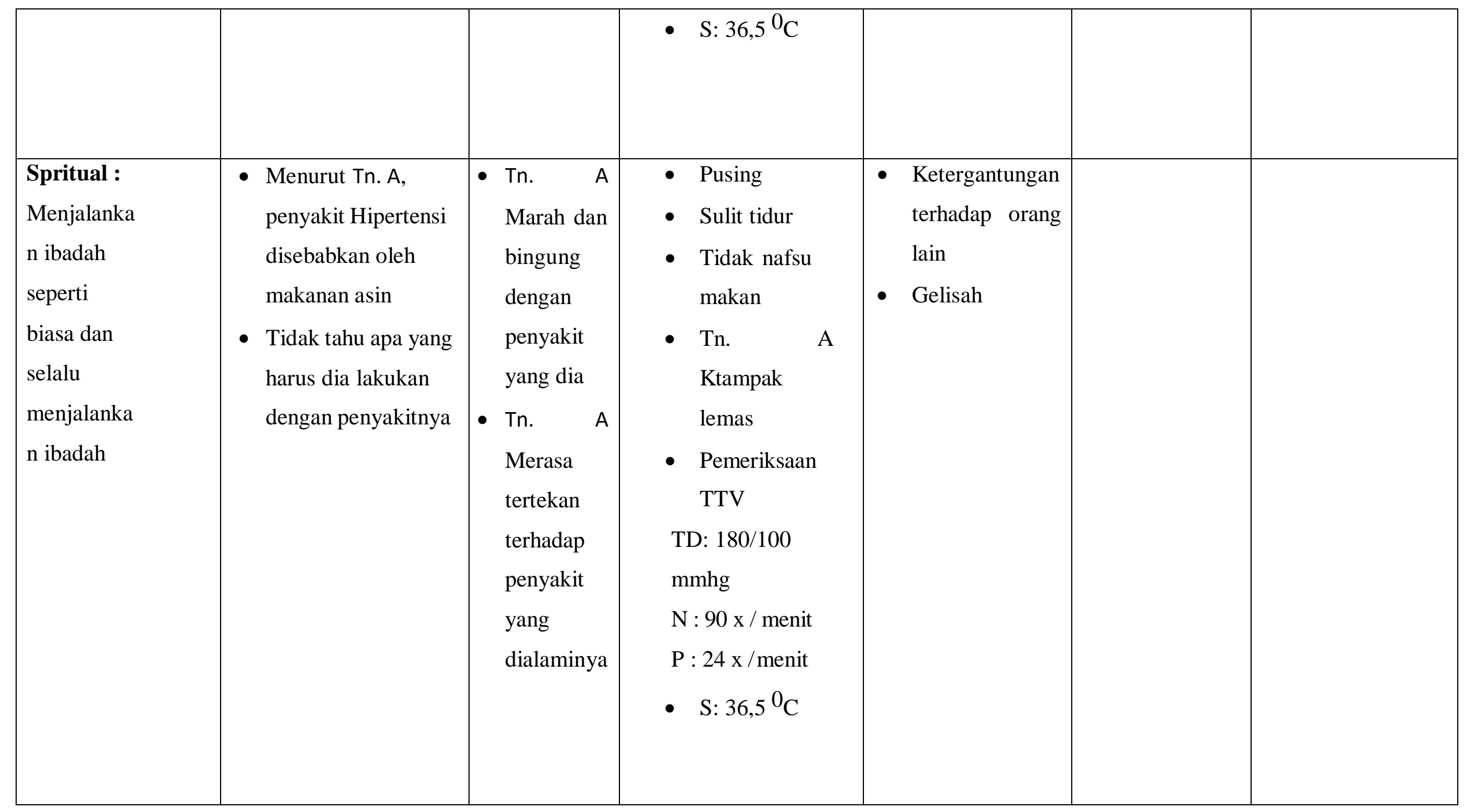


SUMBER KOPING

\begin{tabular}{|c|c|c|c|c|c|}
\hline $\begin{array}{l}\text { DIAGNOSA } \\
\text { KEPERAWATAN }\end{array}$ & PERSONAL ABILITY & SOSIAL SUPPORT & $\begin{array}{l}\text { MATERIAL } \\
\text { ASSETS }\end{array}$ & $\begin{array}{l}\text { POSITIE } \\
\text { BELIEFS }\end{array}$ & TERAPI \\
\hline Ansietas & $\begin{array}{l}\text { - } \text { Tn. A mampu } \\
\text { mengungkapkan } \\
\text { perasaan cemas }\end{array}$ & $\begin{array}{l}\text { - } \text { Tn. A mendapat } \\
\text { dukungan dari } \\
\text { keluarga untuk } \\
\text { kesembuhannya } \\
\text { terutama dari } \\
\text { suaminya }\end{array}$ & $\begin{array}{l}\text { - Ekonomi Tn. A } \\
\text { menengah } \\
\text { - pengobatan } \\
\text { ditanggung } \\
\text { BPJS } \\
\text { - Jarak rumah } \\
\text { Tn. A dengan } \\
\text { tempat } \\
\text { pelayanan } \\
\text { kesehatan } \pm 2 \\
\text { KM }\end{array}$ & $\begin{array}{l}\text { - } \text { Tn. A percayal } \\
\text { bahwa petugas } \\
\text { kesehatan akan } \\
\text { membantunya } \\
\text { - Tn. A berharap } \\
\text { cepat sembuh agar } \\
\text { tidak merepotkan }\end{array}$ & $\begin{array}{l}\text { Terapi spesialis: } \\
\text { - } \text { Relaksasi } \\
\text { progresif } \\
\text { - Psikoedukasi } \\
\text { keluarga } \\
\text { - Behavior therapy } \\
\text { - Psikoedukasi } \\
\text { keluarga }\end{array}$ \\
\hline
\end{tabular}




\begin{tabular}{|c|c|c|c|c|c|}
\hline Ketidakberdayaan & $\begin{array}{l}\text { - Tn. A mengakui bahwa } \\
\text { ia merasa tidak berdaya } \\
\text { untuk melakukan } \\
\text { aktivitas lebih karena } \\
\text { penyakitnya }\end{array}$ & $\begin{array}{lr}\text { Tn. A } & \text { mendapat } \\
\text { dukungan } & \text { dari } \\
\text { keluarga } & \text { untuk } \\
\text { kesembuhannya } \\
\text { terutama dari } \\
\text { istrinya }\end{array}$ & 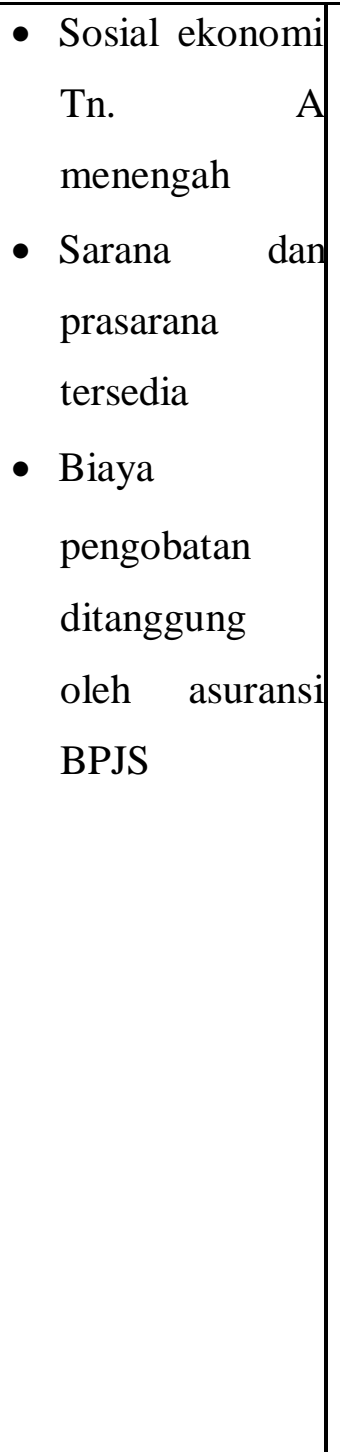 & $\begin{array}{l}\text { - Tn. A percaya } \\
\text { bahwa petugas } \\
\text { kesehatan akan } \\
\text { membantunya } \\
\text { - Tn. A berharap } \\
\text { cepat sembuh agar } \\
\text { tidak merepotkan } \\
\text { - Tn. A selalu berdoa } \\
\text { untuk kesembuhan } \\
\text { penyakitnya } \\
\text { - Tn. A yakin, bila ia } \\
\text { mengikuti petunjuk } \\
\text { dan saran dari } \\
\text { petugas kesehatan } \\
\text { maka ia akan cepat } \\
\text { sembuh } \\
\text { Tn. A yakin istri } \\
\text { dan keluarga } \\
\text { mendukung supaya } \\
\text { lekas sembuh }\end{array}$ & \begin{tabular}{|l} 
Terapi generalis: \\
- SP \\
ketidakberdayaan \\
- Terapi spesialis: \\
- terapi assesment \\
ketidakberdayaa \\
n latihan berpikir \\
positif \\
\end{tabular} \\
\hline
\end{tabular}




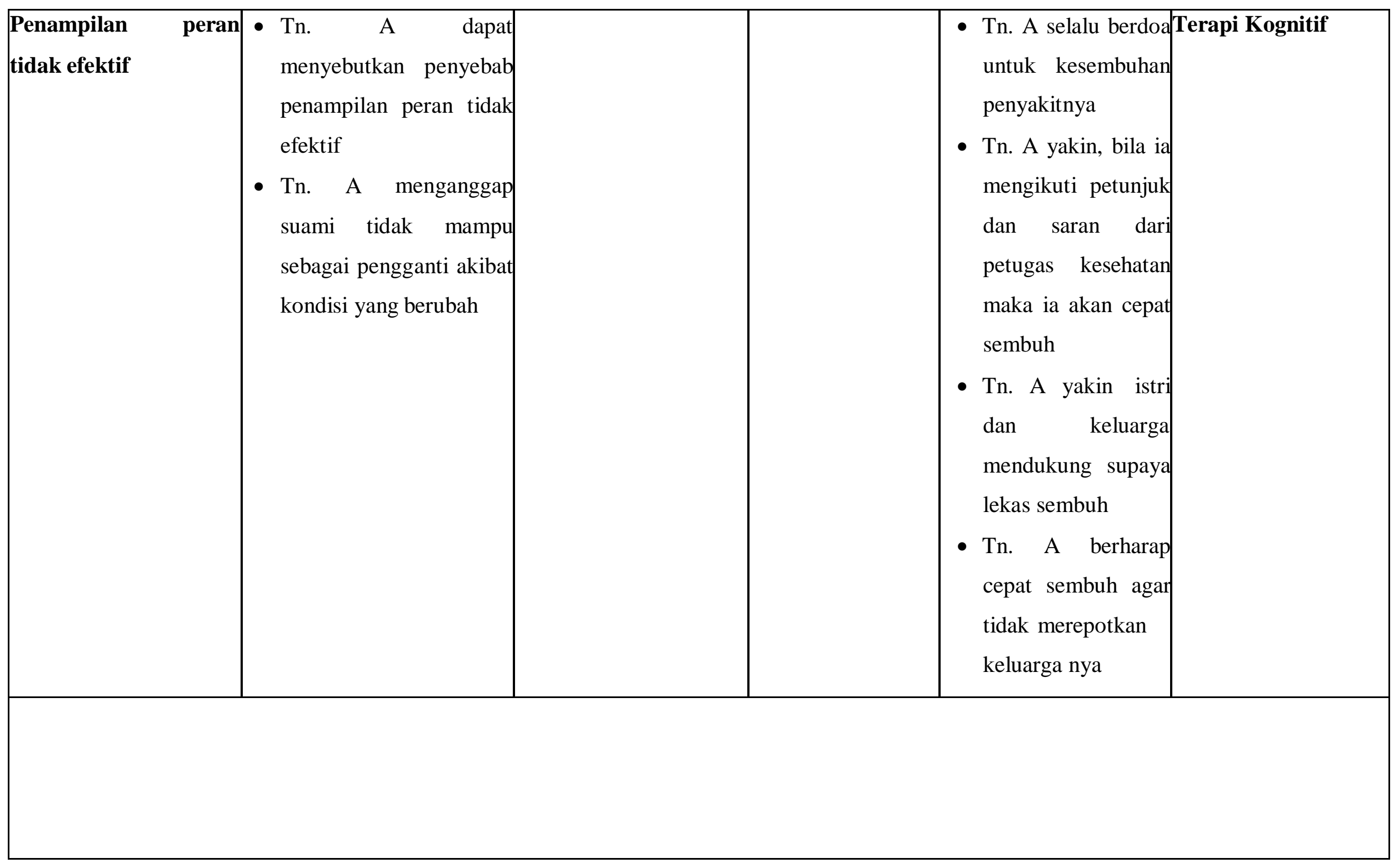


Pohon Diagnosis

Penampilan Peran Tidak Efektif

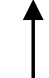

Ketidakberdayaan

$\uparrow$

Kecemasan

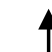

Hipertens 


\section{MEKANISME KOPING}

\begin{tabular}{|c|c|}
\hline HAL YANG DILAKUKAN & ANALISA \\
\hline $\begin{array}{l}\text { - Tn. A mengatakan bila ada masalah, maka ia akan membicarakan } \\
\text { - dengan istri dan keluarga untuk mencari jalan keluarnya } \\
\text { - ke pelayanan kesehatan terdekat } \\
\text { - Tn. A taat menjalankan ibadah sesuai dengan keyakinannya } \\
\text { - Tn. A selalu berdoa kepada Tuhan untuk kesembuhannya }\end{array}$ & $\begin{array}{l}\text { - Konstruktif: } \\
\checkmark \text { Tn. A mengatakan bila ada masalah, maka ia } \\
\text { akan membicarakan dengan suami dan keluarga } \\
\text { untuk mencari jalan keluarnya } \\
\checkmark \text { Bila sakit Tn. A membeli obat di warung dan } \\
\text { berobat ke pelayanan kesehatan } \\
\checkmark \text { Tn. A taat menjalankan ibadah sesuai dengan } \\
\text { keyakinannya } \\
\checkmark \text { Tn. A selalu berdoa kepada Tuhan untuk } \\
\text { kesembuhannya. } \\
\text { Destruktif : - }\end{array}$ \\
\hline
\end{tabular}

\section{STATUS MENTAL}

Kesimpulan : Mental Status Examination (MSE) tidak ada masalah gangguan jiwa, gangguan Tn. A lebih kepada Gangguan Mental Emosional (GME/Psikososial) 


\subsection{DIAGNOSA DAN TERAPI}

\begin{tabular}{|c|c|}
\hline 1. Penampilan & Bersih, rapi, tidak tercium bau, Tn. A tampak gelisah \\
\hline 3. Aktivitas motoric & saat wawancara pasien tampak gelisah \\
\hline 4. Interaksi selama wawancara & Cukup kooperatif \\
\hline 5. Alam perasaan & pasien tampak menunjukkan ekspresi takut dan khawatir \\
\hline 7. Persepsi & Tn. A tidak mengalami gangguan persepsi dan sensori \\
\hline 8. Isi piker & sebagian sudah sulit diingat karena umur sudah tua \\
\hline 9. Proses piker & cukup baik \\
\hline 10. Tingkat kesadaran & Tn. A dapat menyebutkan kembali nama istri \\
\hline 13. Penilaian & Tn. A belum mampu menyebutkan bagaimana caranya agar lekas sembuh \\
\hline 14. Daya tilik diri & $\begin{array}{l}\text { Tn. A menyadari bahwa saat ini ia sedang sakit, Tn. A hanya bisa berdoa supaya lekas sembuh agar tidak terus } \\
\text { merepotkan keluarganya. Tn. A menyadari ia memiliki istri, anak-anak dan keluarga yang menyayanginya dan } \\
\text { mendukung kesembuhannya }\end{array}$ \\
\hline
\end{tabular}




\begin{tabular}{|c|c|}
\hline $\begin{array}{c}\text { DIAGNOSA KEPERAWATAN DAN TERAPI } \\
\text { KEPERAWATAN }\end{array}$ & DIAGNOSA MEDIS \\
\hline $\begin{array}{l}\text { 1. Ansietas } \\
\text { - SP-1 : Kaji tanda dan gejala ansietas dan kemampuan } \\
\text { klien mengurangi kecemasan } \\
\text { - SP-2 : Jelaskan tanda dan gejala, penyebab dan akibat } \\
\text { dari kecemasan } \\
\text { - SP-3 : Latihan cara mengatasi kecemasan : } \\
\checkmark \text { Teknik relaksasi napas dalam } \\
\checkmark \text { Distraksi : bercakap-cakap hal positif } \\
\checkmark \text { Hipnotis } 5 \text { jari fokus padahal-hal yang positif } \\
\text { - SP-4 : Bantu klien melakukan latihan sesuai dengan } \\
\text { jadwal kegiatan } \\
\text { - Terapi Spesialis: TS, PMR, Logo ACT } \\
\text { 2. Ketidakberdayaan } \\
\text { Assesment ketidakberdayaan dan latihan berpikir positif } \\
\text { 3. Penampilan peran tidak efektif } \\
\text { Terapi Kognitif }\end{array}$ & Hipertensi \\
\hline
\end{tabular}




\begin{tabular}{|c|c|}
\hline IMPLEMENTASI TINDAKAN KEPERAWATAN & EVALUASI \\
\hline $\begin{array}{l}\text { Tanggal : } 16 \text { Oktober } 2021 \\
\text { Jam : } 10.00 \text { wib } \\
\text { 1. Melakukan salam teraupetik } \\
\text { 2. Kaji tanda dan gejala ansietas dan kemampuan klien } \\
\text { mengurangi kecemasan } \\
\text { 3. Jelaskan tanda dan gejala, penyebab dan akibat dari } \\
\text { kecemasan } \\
\text { 4. Latihan cara mengatasi kecemasan : } \\
\text { - Teknik relaksasi napas dalam } \\
\text { - Distraksi : bercakap-cakap hal positif } \\
\text { - Hipnotis } 5 \text { jari fokus pada hal-hal yang positif } \\
\text { 5. Bantu klien melakukan latihan sesuai dengan jadwal } \\
\text { kegiatan. }\end{array}$ & 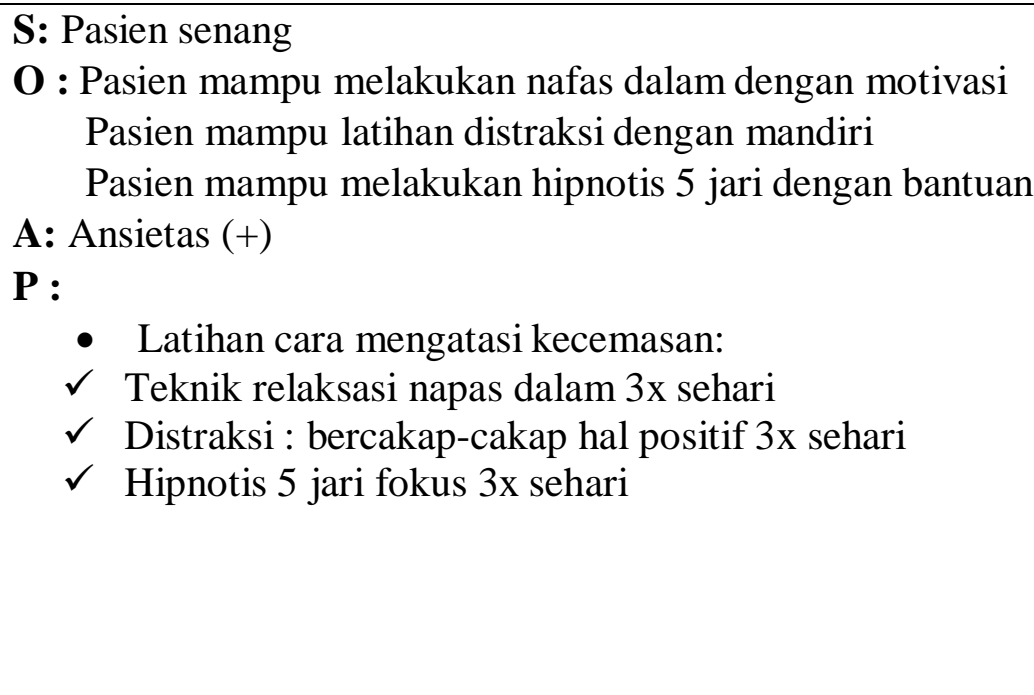 \\
\hline $\begin{array}{l}\text { Tanggal : } 17 \text { Oktober } 2021 \\
\text { Jam : } 10.00 \text { wib } \\
1 \text { Latihan cara mengatasi kecemasan: } \\
\checkmark \text { Teknik relaksasi napas dalam } \\
\checkmark \text { Distraksi : bercakap-cakap hal positif } \\
\checkmark \checkmark \text { Hipnotis } 5 \text { jari fokus pada hal-hal yang positif } \\
2 \text { Bantu klien melakukan latihan sesuai dengan jadwal } \\
\text { kegiatan }\end{array}$ & $\begin{array}{l}\text { S: Pasien senang } \\
\text { O: Pasien mampu melakukan nanfas dalam dengan motivasi } \\
\quad \text { Pasien mampu latihan distraksi dengan mandiri } \\
\quad \text { Pasien mampu melakukan hipnotis } 5 \text { jari dengan bantuan } \\
\text { A: Ansietas (-) } \\
\text { P: } \\
\text { - Latihan relaksasi nafas dalam } 3 x \text { sehari } \\
\text { - Distraksi 3x sehari }\end{array}$ \\
\hline
\end{tabular}


Tanggal : 18 Oktober 2021

Jam : 14.00 wib

1 Latihan cara mengatasi kecemasan :

$\checkmark$ Teknik relaksasi napas dalam

$\checkmark$ Distraksi : bercakap-cakap hal positif

$\checkmark$ Hipnotis 5 jari fokus pada hal-hal yang positif

2 Bantu klien melakukan latihan sesuai dengan jadwal kegiatan

Tanggal 19 Oktober 2021

Jam: 10.00 wib

1 Latihan cara mengatasi kecemasan :

$\checkmark$ Teknik relaksasi napas dalam

$\checkmark$ Distraksi : bercakap-cakap hal positif

$\checkmark$ Hipnotis 5 jari fokus pada hal-hal yang positif

2 Bantu klien melakukan latihan sesuai dengan jadwal kegiatan

\section{Tanggal 20 Oktober 2021}

Jam: $10.00 \mathrm{wib}$

1 Latihan cara mengatasi kecemasan :

$\checkmark$ Teknik relaksasi napas dalam

$\checkmark$ Distraksi : bercakap-cakap hal positif

$\checkmark$ Hipnotis 5 jari fokus pada hal-hal yang positif
- Latihan hipnotis 5 jari 3x sehari

S : Pasien senang

O: Pasien mampu melakukan nanfas dalam dengan motivasi

Pasien mampu latihan distraksi dengan mandiri

Pasien mampu melakukan hipnotis 5 jari dengan bantuan

A:Ansietas (-)

P:

- Latihan relaksasi nafas dalam 3x sehari

- Distraksi 3x sehari

- Latihan hipnotis 5 jari 3x sehari

S : Klien mengatakan ansietasnya sudah berkurang, pasien

sudah merasa lebih tenang.

O:Pasien mampu melakukan nanfas dalam dengan motivasi

Pasien mampu latihan distraksi dengan mandiri

Pasien mampu melakukan hipnotis 5 jari dengan bantuan.

A:Ansietas (-)

P:

- Latihan relaksasi nafas dalam 3x sehari

- Distraksi 3x sehari

- Latihan hipnotis 5 jari 3x sehari

\section{S: senang}

O:Pasien mampu melakukan nanfas dalam dengan motivasi

Pasien mampu latihan distraksi dengan mandiri

Pasien mampu melakukan hipnotis 5 jari dengan bantuan

A:Ansietas (-)

P:

- Latihan relaksasi nafas dalam 3x sehari

- Distraksi 3x sehari 
2 Bantu klien melakukan latihan sesuai dengan jadwal kegiatan

Tanggal 21 Oktober 2021

Jam: $10.00 \mathrm{wib}$

1 Latihan cara mengatasi kecemasan :

$\checkmark$ Teknik relaksasi napas dalam

$\checkmark$ Distraksi : bercakap-cakap hal positif

$\checkmark$ Hipnotis 5 jari fokus pada hal-hal yang positif

2 Bantu klien melakukan latihan sesuai dengan jadwal kegiatan
- Latihan hipnotis 5 jari 3x sehari

\section{S: Pasien senang}

$\mathbf{O}$ : Pasien mampu melakukan nafas dalam dengan motivasi

Pasien mampu latihan distraksi dengan mandiri

Pasien mampu melakukan hipnotis 5 jari dengan bantuan

A: Ansietas (-)

P : Latihan relaksasi nafas dalam 3x sehari

- Distraksi 3x sehari

- Latihan hipnotis 5 jari 3x sehari 


\section{BAB 4 \\ PEMBAHASAN}

\section{Tahap Pengkajian}

Selama pengkajian dilakukan pengumpulan data dari beberapa sumber, yaitu dari pasien dan tetangga sekitar. Maka penulis melakukan pendekatan kepada pasien melalui komunikasi teraupetik yang lebih terbuka membantu klien untuk mengatasi perasaannya dan juga melakukan observasi kepada pasien. Adapun upaya tersebut yaitu

a. Melakukan pendekatan dan membina hubungan saling percaya diri pada klien agar klien lebih terbuka dan lebih percaya dengan menggunakan perasaan.

b. Mengadakan pengkajian klien dengan wawancara dalam pengkajian ini, penulis tidak menemukan kesenjangan karena ditemukan hal sama seperti: diteori: ketidakberdayaan merupakan fisiologis dari penyakit pasien, tanpa objek yang spesifik karena ketidaktahuan dan mendahului pengalamanya yang baru seperti penyakitnya saat ini

\section{Tahap Perencanaan}

Perencanaan dalam proses keperawatan lebih dikenal dengan rencana asuhan keperawatan yang merupakan tahap selanjutnya setelah pangkajian dan penentuan diagnosa keperawatan. Pada tahap perencanaan penulis hanya menyusun rencana tindakan keperawatan sesuai dengan pohon masalah keperawatan yaitu : Kecemasan. Pada tahap ini antara tinjauan teoritis dan tinjaun kasus tidak ada kesenjangan sehingga penulis dapat melaksanakan tindakan seoptimal mungkin dan didukung dengan seringnya bimbingan dengan pembimbing. Secara teoritis digunakan cara strategi pertemuan sesuai dengan diagnosa keperawatan yang muncul saat pengkajian. Adapun upaya yang dilakukan penulis yaitu :

1. Klien menunjukan sikap marah dan tertekan terhadap perburukan fisik yang terjadi dengan mengabaikan kepatuhan pasien terhadap program pengobatan

2. Klien mengalami ketergantungan pada orang lain yang dapat mengakibatkan ititabilitas, ketidaksukaan, marah dan rasa bersalah. Klien tidak melakukan praktik perawatan diri ketika ditantang. Klien tidak ikut memantau kemajuan pengobatan. Klien menunjukan ekspresi ketidakpuasan terhadap ketidakmampuan melakukan 
aktivitas atau tugas sebelumnya. Klien menunjukan ekspresi keraguan tantang performa peran.

\section{Tahap Implementasi}

Pada tahap implementasi, penulis hanya mengatasi 3 masalah keperawatan yakni: diagnosa keperawatan, Kecemasan, ketidakberdayaan dan penampilan peran tidak efektif merupakan keadaan emosi dan pengalaman subyektif induvidu, tanpa objek spesifik karena ketidaktahuan dan mendahului semua pengalaman yang di alami penyakit Hiperteni

\section{Tahap Evaluasi}

Pada tinjauan teoritis evaluasi yang diharapkan adalah :

a. Membina hubungan saling percaya

b. Mengenali dan mengekspresikan emosinya

c. Mampu mengenal ketidakberdayaan

d. Mampu mengatasi kecemasan dengan aspek positif

e. Mampu mengembangkan harapan positif dan latihan mengontrol perasaan 


\section{BAB 5}

\section{PENUTUP}

\section{Kesimpulan}

Berdasarkan uraian pada pembahasan diatas, maka penulis dapat disimpulkan bahwa:

1) Pengkajian dilakukan secara langsung pada klien dan juga dengan menjadikan status klien sebagai sumber informasi yang dapat mendukung data-data pengkajian. Selama proses pengkajian, perawat mengunakan komunikasi terapeutik serta membina hubungan saling percaya antara perawat-klien. Pada kasus Kecemasan : Hipertensi

2) Diagnosa keperawatan yang utama pada klien dengan kasus Kecemasan : Hipertensi Perencanaan intervensi dan implementasi keperawatan disesuaikan dengan strategi pertemuan pada pasien.

3) Evaluasi keperawatan yang dilakukan menggunakan metode subyektif, obyektif ,assessment dan planing.

\section{Saran}

1. Untuk Keluarga

Diharapkan agar individu dan keluarga bisa mengerti tentang penyakit hipertensi, dan meningkatkan perilaku hidup sehat dengan tujuan meningkatkan kualitas hidup.

2. Untuk Masyarakat/Pembaca

Diharapkan kasus dan materi ini dapat dijadikan sebagai bahan ajar dan data untuk menangani dan menghadapi kasus kecemasan pada masalah psikososial. 


\section{DAFTAR PUSTAKA}

1. Andrian P. N. (2016). Hubungan Konsumsi Makanan dan Kejadian Hipertensi pada Lansia di Puskesmas Ranomut Kota Manado

2. Hulu, E. K., \& Pardede, J. A. (2016). Dukungan Keluarga Dengan Tingkat Kecemasan Pasien Pre Operatif Di Rumah Sakit Sari Mutiara Medan. Jurnal Keperawatan, 2(1), 12.

3. Keliat, B.A., Hamid, A.Y.S., Putri, Y.S.E. (2019). Asuhan Keperawatan Jiwa. Jakarta : EGC

4. Lestari, A. (2018). Pengaruh Terapi Psikoedukasi Keluarga Terhadap Pengetahuan Dan Tingkat Ansietas Keluarga Dalam Mera Wat Anggota Keluarga Yang Mengalami Tuberculosis Paru Di Kota Bandar Lampung. Jurnal Ilmiah Kesehatan, 1(1). https://doi.org/10.35952/jik.v1i1.105

5. Marbun, A., Pardede, J. A., \& Perkasa, S. I. (2019). Efektivitas Terapi Hipnotis Lima Jari terhadap Kecemasan Ibu Pre Partum di Klinik Chelsea Husada Tanjung Beringin Kabupaten Serdang Bedagai. Jurnal Keperawatan Priority, 2(2), 92-99. https://doi.org/10.34012/jukep.v2i2.568

6. Pardede, J. A., \& Simangunsong, M. M. (2020). Family Support With The Level of Preschool Children Anxiety in the Intravenous Installation. Jurnal Keperawatan Jiwa (JKJ): Persatuan Perawat Nasional Indonesia, 8(3), 223-234.

https://doi.org/10.26714/jkj.8.3.2020.223-234

7. Pardede, J. A. (2020). Standar Asuhan Keperawatan Jiwa Dengan Masalah Kecemasan.

8. Pardede, JA, Keliat, BA, Damanik, RK, \& Gulo, ARB (2020). Optimalisasi Coping Perawat dalam Mengatasi Kecemasan di Masa Pandemi Covid-19 di Era New Normal. Jurnal Peduli Masyarakat, 2 (3), 105-112. https://doi.org/10.37287/jpm.v2i3.128

9. Pardede, J., Simanjuntak, G. V., \& Manalu, N. (2020). Effectiveness of deep breath relaxation and lavender aromatherapy against preoperative patient anxiety. Diversity and Equality in Health and Care, 17(4), 168-173.

10. Pardede, J. A., Hasibuan, E. K., \& Hondro, H. S. (2020). Perilaku Caring Perawat Dengan Koping Dan Kecemasan Keluarga. Indonesian Journal of Nursing Sciences and Practice, 3(1), 14-22. https://doi.org/10.24853/ijnsp.v3i1.14-22

11. Pome, G., Endriyani, S., \& Rizal, F. (2019). Pengaruh Teknik Relaksasi Progresif terhadap Penurunan Tingkat Kecemasan pada Pasien Hipertensi di Puskesmas Makrayu Palembang. Jurnal Keperawatan Sriwijaya, 6(2), 1-6.

12. Siregar, N.Y., Klas, C.F.,Nurfatimah, dkk. (2021). Tingkat Kecemasan Ibu Hamil Trimester ke III Dalam Menghadapi Persalinan. Jurnal Bidan Cerdas, Vol.3 Nomor 1, $18-28$ 
13. Stuart. Gail. W, Keliat. Budi. Anna,\& Pasaribu. Jesika.(2016). Keperawatan kesehatan jiwa : Indonesia : Elsever.

14. Susilowati, T., Pramana, N., Muis, S. F. (2019). Intervensi non Farmakologi Terhadap Kecemasan Pada Primigravida. Jurnal Ilmiah Stikes Kendal, Vol 9, Nomor 3, ISSN 2549-8134, hal 181-186.

15. Triyanto, Endang. (2014).Pelayanan Keperawatan Bagi Penderita Hipertensi SecaraTerpadu. Yogyakarta: Graha Ilmu.

16. Pardede, J. A., Sitepu, S. F. A., \& Saragih, M. (2018). The Influence of Deep Breath Relaxation Techniques and Five-Finger Hypnotic Therapy on Preoperative Patient Anxiety. Journal of Psychiatry, 3(1), 1-8.

17. Pardede, J. A., \& Simanjuntak, G. V. (2020). Overcoming Anxiety During the Covid-19 Using Five-finger Hypnotic Therapy.

18. Pardede, J. A. (2021). Standar Asuhan Keperawatan Dengan Kesiapan Peningkatan Pengetahuan.

19. Wardayati, K.T. (2011). Polusi perkotaan pemicu hipertensi. 10 Juni 2013. http://intisarionline.com/read/polusi-perkotaan-pemicu-hipertensi

20. WHO (2011) 'Global status report on noncommunicable diseases 2010', World Health Organization, p. 176.

21. Wijaya, A. S. and Putri, Y. M. (2013) Kmb 1 Keperawatan Medikal Bedah (Keperawatan Dewasa). Yogyakarta: Nurha Medika.

22. Widiyani, R. (2013). Penderita hipertensi terus meningkat. Jakarta: EGC Wiguna. (2003). Istilah Kesehatan Jiwa dan Psikiatrik. Jakarta:EGC

23. Yuwono, G. A., Ridwan, M., \& Hanafi, M. (2018). Pengaruh Pendidikan Kesehatan Tentang Hipertensi Terhadap Tingkat Kecemasan Pada Penderita Hipertensi Di Kabupaten Magelang. Jurnal Keperawatan Soedirman, 12(1), 55-66. http://dx.doi.org/10.20884/1.jks.2017.12.1.687 
